\title{
CÓDIGO FLORESTAL, FUNCÃO SOCIOAMBIENTAL DA TERRA E SOBERANIA ALIMENTAR
}

\author{
Sérgio Sauer* \\ Franciney Carreiro de França ${ }^{* *}$
}

\begin{abstract}
O presente artigo tem como objetivo discutir alterações do Código Florestal, especialmente as propostas de mudanças nas noções de Reserva Legal e Área de Preservação Permanente (APP), em processo de rediscussão no Congresso, após sanção presidencial com vetos no texto aprovado na Câmara em 25 de abril de 2012. Para suprir lacunas da nova Lei, o Executivo Federal editou a Medida Provisória (MP) 571/2012, que retoma a discussão da matéria. Tanto dispositivos da nova Lei como alterações propostas ao texto da MP geram insegurança alimentar e visam a eliminar a função socioambiental da terra. A motivação das mudanças não está relacionada à sustentabilidade ambiental ou às mudanças climáticas, temas fundamentais na agenda mundial, mas parte do princípio de que a natureza é um empecilho ao desenvolvimento. Este artigo resgata as principais alterações no Código Florestal relacionadas à Reserva Legal e às APPs, estabelecendo relações (impactos negativos) com a função socioambiental da terra e a soberania alimentar.
\end{abstract}

PALAvRAS-CHAvE: Código ambiental, função socioambiental da terra, segurança alimentar, sustentabilidade.

\section{INTRODUÇÃO}

Discussões e propostas de mudança no chamado Código Florestal, Lei 4.771 de 1965, se não foram as mais polêmicas, estiveram entre os assuntos de maior tensão e provocaram grandes enfrentamentos parlamentares em 2011 e 2012. O Projeto de Lei (PL) n $\mathrm{n}^{0}$ 1.876, de 1999, apreciado na Câmara dos Deputados, e o Projeto de Lei da Câmara (PLC) $n^{\circ}$ 30, de 2011, discutido no Senado Federal e novamente alterado pela Câmara dos Deputados, foram objeto de intensos debates, envolvendo, inclusive, diversos setores da sociedade brasileira, com ampla repercussão na opinião pública nacional.

Apesar de reconhecermos a importância do debate parlamentar, as polêmicas e atritos

* Doutor em Sociologia. Professor da Universidade de Brasília (UnB), campus de Planaltina (FUP), e do Programa de Pós Graduação em Meio Ambiente e Desenvolvimento Rural (PPG-MADER/FUP).

Universidade de Brasília, UnB - Planaltina (FUP). Planaltina. Cep: 70910-900 - Brasilia, DF - Brasil. sauer.sergio@gmail.com

* * Doutora em Arquitetura e Urbanismo (FAU/UnB), Bacharel em Matemática (UFG) e assessora técnica do Senado Federal.francic@senado.gov.br não são a motivação central das reflexões que se seguem. Também não é objetivo fazer uma avaliação da correlação de forças internas no Parlamento, ou de todas as propostas apresentadas, nem do resultado final desse debate, inclusive porque a matéria ainda está em discussão no Congresso Nacional, após a edição da Medida Provisória (MP) no 571, de 2012, e não temos um texto final. A motivação principal está diretamente relacionada à tese de que as mudanças propostas ao Código Florestal, em processo de discussão no Congresso, após sanção e edição de Medida Provisória, geram insegurança alimentar e visam a eliminar a função socioambiental da terra no Brasil.

Conforme veremos nas reflexões que se seguem, a base ou a motivação central para as mudanças propostas não está relacionada à preocupação com a sustentabilidade ambiental ou com as mudanças climáticas, temas fundamentais na agenda política mundial e pautas da Rio+20. Ao contrário, todas as propostas de alteração, como, por exemplo, a redução das Áreas de Preservação Permanente (APPs) ou da Re- 
serva Legal - quando não de sua total supressão - partem do princípio de que a natureza (a floresta ou a mata) é um empecilho ao desenvolvimento, entendido apenas como crescimento econômico. Sustentadas por princípios avessos a qualquer preservacionismo, as propostas e a defesa de mudanças têm como justificativa a necessidade de manter ou ampliar a área de cultivo para a agropecuária, aproveitando as oportunidades de negócios e dando maior competitividade ao setor. Em outras palavras, justificam-se para não “escorraçar plantações” e “colocar mata no lugar” (Rebelo, 2011a).

O deputado Onyx Lorenzoni (DEM/RS), em discurso no plenário da Câmara em 11 de maio de 2011, expressou claramente uma das principais oposições ideológicas ao texto atual do Código e as intenções em torno das mudanças propostas. Segundo o deputado, o instituto da Reserva Legal é uma "aberração” e um "absurdo, porque é confisco de propriedade”. Ainda segundo o deputado, “[...] só no Brasil existe a Reserva Legal, que subtrai, rouba, sequestra, confisca $20 \%$ da propriedade rural brasileira". Na mesma toada, finaliza seu discurso contra o instituto da Reserva Legal, transformando o direito de propriedade em sinônimo de democracia. Segundo o deputado, “[...] o direito de pro- ma restrição à exploração de seus recursos. Consequentemente, negam que o meio ambiente e a natureza são bens comuns e não individuais ou privados (art.225, da Constituição Federal) e que sua preservação é também uma exigência constitucional (art.186).

No polo oposto, militantes ambientalistas, lideranças agrárias e pesquisadores - a exemplo dos que produziram estudos para a Sociedade Brasileira para o Progresso da Ciência (SBPC) e para a Academia Brasileira de Ciências (ABC) defendem que não há contradição séria entre a produção de alimentos e a conservação do meio ambiente no arcabouço legal brasileiro. Nesse sentido, advogam que a terra não é só um meio (tradicional) de produção, mas nela estão incluídos seus recursos (água, subsolo, florestas, fauna etc.). Portanto, ela constitui um bem comum, que não pode ser apropriado e utilizado apenas por interesses privados.

Apesar de os textos aprovados nas duas Casas Legislativas tratarem de muitos aspectos relacionados ao meio ambiente, entendemos que questões relativas a Áreas de Preservação Permanente e Reserva Legal devem ser "[...] parte fundamental do planejamento agrícola conservacionista" (ABC; SBPC, 2011, p.10), especialmente porque impactam diretamente sobre a produção de alimentos e sobre a função socioambiental da terra. Consequentemente, este artigo tem início com um resgate de algumas propostas de mudanças no Código, suas motivações e consequências (Parte 1), passando à discussão sobre a função socioambiental da terra e o lugar e a importância da Reserva Legal (Parte 2). Na sequência (Parte 3), relacionamos a realidade, histórica e atual de concentração da propriedade da terra com a insustentabilidade ambiental (superexploração da natureza) e a insegurança alimentar, agravadas especialmente pelas tentativas de subtração das Áreas de Preservação Permanente. 


\section{CÓDIGO FLORESTAL: história, característi- cas e propostas de mudanças}

O primeiro Código Florestal brasileiro data de 1934 e foi criado para normatizar o uso das florestas. ${ }^{1}$ Em seu artigo $1^{\circ}$, expressava a preocupação de considerar as florestas nacionais em seu conjunto, reconhecendo-as como de interesse social. Definindo as florestas como um bem jurídico de interesse comum, estabeleceu a reserva obrigatória de $25 \%$ de vegetação nativa nas propriedades rurais (art. 23).

A partir de sua aprovação, em 1934, o Código Florestal foi alterado diversas vezes. Em vigor até 2012 estava a Lei 4.771, de 1965, agora revogada pela Lei 12.651, de 2012. A Lei 4.771 estabeleceu dois mecanismos importantes de proteção ambiental: a) a Área de Preservação Permanente (APP), destinada a proteger o solo e as águas, cujo uso é limitado e depende de situações a serem autorizadas pelo poder público; b) a Reserva Legal, como um percentual do imóvel que deve ser coberto por vegetação natural e que pode ser explorada com manejo florestal sustentável.

Após muitas mudanças, o percentual de cobertura vegetal exigido para compor a Reserva Legal continua sendo de $80 \%$ em floresta e $35 \%$ em cerrado na Amazônia Legal, e 20\% no restante do Brasil. No caso da Reserva Legal em área de floresta da Amazônia, durante muitos anos, o percentual exigido era de $50 \%$, mas passou para $80 \%$ com a Medida Provisória 1.511, de 1996, reeditada várias vezes. Esse aumento foi introduzido como uma tentativa de frear o desmatamento em processo de crescimento na região Amazônica (França et al., 2011).

A MP 1.511 foi editada como uma tentativa de diminuir o desmatamento na Amazônia, em resposta à opinião pública nacional e inter-

\footnotetext{
${ }^{1}$ Consta da historiografia que leis florestais são ainda mais antigas no Brasil. Um dos primeiros instrumentos de controle de ações antrópicas sobre florestas foi a carta de Lei de 16 de outubro de 1827 . O objetivo era o de conter o contrabando e evitar o desabastecimento de um produto, à época considerado estratégico - as madeiras de alta qualidade para fins navais e que tinham alto valor comercial. Mas é em 1934 que surge a primeira consolidação das leis florestais (França et al., 2011).
}

nacional. Apesar da realização da Eco'92² e dos compromissos nela assumidos pelo Brasil, inclusive com a implantação do Programa Piloto para a Proteção das Florestas Tropicais do Brasil (PPG7), o desmatamento, na Amazônia, continuava em forte crescimento, exigindo ações concretas do Executivo Federal, o que resultou na edição da referida MP.

Além das dimensões da Reserva Legal, os limites das Áreas de Preservação Permanente também foram alterados nas últimas décadas. Por exemplo, a Lei 7.511, de 1986, aumentou a largura da mata ciliar, após os desastres naturais que ocorreram na época. Passados três anos, a largura das APPs ripárias (matas ciliares) foi novamente alterada pela Lei 7.830 , de $1989,{ }^{3}$ consolidando as faixas de mata ciliar em vigor no Código Florestal.

Em 2001, por meio da Medida Provisória 2.166 67, foram promovidas outras alterações no Código Florestal, como, por exemplo, a inclusão dos conceitos de "utilidade pública" e "interesse social” (art.1 $1^{\circ}, \S 1^{\circ}$, IV e V). Entre as mudanças, a MP estabeleceu ainda regras para delimitação e registro de Reserva Legal e regras para sua recomposição. Essa recomposição deveria ser no mesmo ecossistema e na mesma microbacia (art. 44, III), ou em área mais próxima da propriedade, desde que na mesma bacia hidrográfica e no mesmo Estado (art. 44, § $4^{\circ}$ ).

Em 2008, duas medidas contribuíram para aumentar a pressão pela reformulação do Código Florestal. A primeira foi a edição da Resolução ${ }^{\circ}$ 3.545, de 2008, do Banco Central, que passou a exigir documentação para comprovar a regularidade ambiental para fins de financiamento

${ }^{2}$ A Conferência das Nações Unidas sobre o Meio Ambiente e o Desenvolvimento (CNUMAD), realizada em 1992, na cidade do Rio de Janeiro, ficou conhecida como Eco'92, Rio'92 ou ainda Cúpula da Terra, a qual tinha como objetivo estabelecer acordos entre países na promoção do desenvolvimento sustentável.

${ }^{3}$ Essa lei manteve as faixas de $30 \mathrm{~m}$ (para cursos d'água de menos de $10 \mathrm{~m}$ de largura) e de 50m (para os cursos d'água entre 10 a 50m de largura), mas alterou as demais faixas, que haviam sido estabelecidas pela Lei 7.511: a) 100m para os cursos d'água entre 50 a $200 \mathrm{~m}$ de largura; b) de $200 \mathrm{~m}$ para os cursos d'água entre de 200 a $600 \mathrm{~m}$; c) de $500 \mathrm{~m}$ para os cursos d'água que tenham largura superior a $600 \mathrm{~m}$. 
agropecuário no bioma Amazônia. A segunda foi a edição do Decreto $n^{\circ} 6.514$, de 2008, que passou a exigir a regulamentação da Reserva Legal e definiu multas para o caso de não efetivação da averbação. ${ }^{4}$

O Decreto 6.514 estabeleceu as sanções penais e a data para o início dessas medidas (art.55). O prazo, inicialmente previsto para 22 de julho de 2008, foi prorrogado algumas vezes, sendo que a penúltima alteração estabelecia a data de 11 de junho de 2011 (Decreto n7.029, de 2009). Essa data-limite tensionou sobremaneira o processo e foi usada para apressar a tramitação da matéria no Parlamento, especialmente devido ao argumento de que os pequenos agricultores seriam responsabilizados criminalmente caso o Decreto entrasse em vigor. Esse foi o argumento utilizado para pressionar o Governo Federal, levando à edição do Decreto n ${ }^{\circ} 7.640$, em 2011, prorrogando a vigência do Decreto 6.514, de 2008, para 11 de abril de 2012, novamente prorrogada para 11 de junho de 2012, por meio do Decreto $n^{0} 7.719 / 2012$.

$\mathrm{O}$ argumento sobre a necessidade de regularizar um fato ou situação consumada foi utilizado à exaustão para justificar as propostas de alteração no Código Florestal. Ao longo da discussão e tramitação da matéria, tanto parlamentares como setores da sociedade defenderam mudanças, como se o problema fosse a legislação em vigor, e não as ações à revelia dela. As afirmações do deputado Aldo Rebelo explicitam tal intenção ao declarar que a Câmara deveria votar as alterações “[...] para responder a necessidade inadiável: a adequação da legislação atual, que põe na ilegalidade praticamente 100\% dos pequenos e médios agricultores do País.” (Rebelo, 2011 - ênfases nossas).

Em primeiro lugar, consideramos que essa naturalização de uma "situação dada" configura o que pode ser resumido pela expressão "legalizar a ilegalidade”. Há uma inversão no argumento, pois o problema passa a ser a existência de uma legis-

${ }^{4}$ O Decreto ${ }^{\circ}$ 6.514, de 2008, substituiu o Decreto 3.179 de 1999, o primeiro que regulamentou a Lei 9.605, de 1998, denominada Lei de Crimes Ambientais. lação e não as ações que não a respeitaram. Em segundo lugar, destacamos que a situação dos pequenos e médios agricultores foi utilizada como desculpa para sensibilizar a opinião pública, como se, nesse segmento, se encontrasse o maior passivo ambiental. Segundo Kátia Abreu (2011a),

[...] 90\% são pequenos e médios. Para ser mais precisa, $86 \%$ são pequenos e $12 \%$ são médios agricultores. Esses são a causa da nossa ansiedade, porque os grandes, felizmente, os ricos já conseguiram se adequar à lei, gastaram dinheiro. [...] mas, para um pequeno agricultor e um médio agricultor, faz toda a diferença (ênfases nossas).

Vale destacar que não fica claro, no trecho do discurso acima, qual é o real significado de "a diferença" para os pequenos, mas certamente não se refere a uma solução para a falta do principal meio de vida e produção (a terra) para esses agricultores. De acordo com estudos do Instituto de Pesquisa Econômica Aplicada - IPEA (2011, p.9), a liberação da Reserva Legal para uso produtivo (um dos argumentos na defesa das mudanças em favor dos pequenos) não faria diferença significativa na disponibilização de mais terras e, portanto, não resolve a histórica falta de área para cultivos nos minifúndios.

Por outro lado, o problema do descumprimento da legislação ambiental em vigor, ou o passivo ambiental, não se concentra nesse segmento social. Os dados utilizados mascaram uma falsa justificativa, pois $86 \%$ - mais precisamente, $84,4 \%$ - se referem ao número de estabelecimentos classificados como agricultores familiares (5.175.489 estabelecimentos) pelo Censo Agropecuário, segundo critérios da Lei 11.326, de 2006, e não à área desse segmento, que representa apenas 24,3\% (80 milhões de hectares) da área total dos estabelecimentos (IBGE, 2009a).

Com base nos dados do Sistema Nacional de Cadastro Rural (SNCR), do Instituto Nacional de Colonização e Reforma Agrária (INCRA), o estudo do IPEA (2011) aponta a perspectiva de que o maior passivo ambiental deve se concentrar nas grandes propriedades, se tomarmos em conta a área ocupada por esses imóveis. Isso 
porque, apesar de representar 65\% dos imóveis, os minifúndios detêm apenas $8 \%$ da área total, ou seja, 48,3 milhões de hectares (IPEA, 2011, p.8). ${ }^{5}$ Tanto em relação à área ocupada pela agricultura familiar como à área total dos minifúndios, proporcionalmente, o passivo ambiental não está localizado nas propriedades desses agricultores.

Devido às exigências de cumprimento das normas ambientais e à necessidade de "atender aos pequenos agricultores" (Rebelo, 2011b), uma Comissão Especial foi criada, nos termos do art. 34, II, do Regimento Interno da Câmara dos Deputados, em setembro de 2009, para apreciar várias propostas de reformulação do Código Florestal, tendo como base o Projeto de Lei ${ }^{\circ} 1876$, de 1999, de autoria do Dep. Sérgio Carvalho (PSDB/RO). Esse projeto tramitava na Câmara desde 1999 e dispunha sobre Áreas de Preservação Permanente, Reserva Legal e exploração florestal, propondo a revogação do Código de 1965. A esse projeto foram apensadas dez proposições, dando início ao intenso debate que marcou a sua tramitação, cuja relatoria ficou a cargo do Dep. Aldo Rebelo (PCdoB/SP), na Câmara, e dos Senadores Jorge Viana (PT/AC) e Luiz Henrique da Silveira (PMDB/SC), no Senado.

Conforme foi amplamente noticiado, os debates foram acirrados, e as propostas de modificação as mais diversas. No entanto, dentre as novidades promovidas pela Câmara, ratificadas no Senado e sancionadas pela Lei 12.651/2012, está a inserção do conceito de "área rural consolidada”. ${ }^{6} \mathrm{O}$ texto aprovado no Senado não mudou a essência do texto da Câmara, mantendo a definição de área rural consolidada como qual-

${ }^{5}$ É importante observar aqui que as diferenças percentuais não se referem apenas às duas fontes distintas de dados, ou seja, Censo Agropecuário do IBGE e Cadastro do INCRA, mas ao uso de conceitos distintos, pois agricultura familiar é uma combinação de vários critérios, sendo um a dimensão da área (até quatro módulos) e minifúndio é uma noção que se aplica a todos os imóveis com área inferior a um módulo fiscal.

${ }^{6}$ A área rural consolidada foi definida como "área de imóvel rural com ocupação antrópica pré-existente a 22 de julho de 2008, com edificações, benfeitorias ou atividades agrossilvopastoris, admitida, nesse último caso, a adoção do regime de pousio" (Viana, 2011, art. $3^{\circ}$, IV; redação semelhante em Rebelo, 2010a, art. $3^{\circ}$, III; Lei 12.651/2012, art.3 ${ }^{\circ}$, IV). quer área já ocupada antes de 22 de julho de 2008, independentemente das demais características do local. Em outras palavras, área de proteção permanente irregularmente utilizada, encosta de morro desmatada, Reserva Legal usada com lavoura ou pastagem, ou qualquer outra ocupação de área que deveria ser preservada ou conservada, até a data de 22/07/2008, serão consideradas como áreas consolidadas.

É importante observar que essa data não é aleatória, mas foi escolhida porque é o dia da edição do Decreto 6.514/2008. O Dep. Aldo Rebelo utilizou esse decreto como um "marco zero", e tudo que ocorreu, a título de desmatamentos irregulares, anteriormente a ele fica sem efeito se cumpridas algumas condições impostas nessa nova lei (França et al., 2011). Infelizmente, os mecanismos criados para a regularização, fundamentados nos pilares de recomposição e (ou) compensação, ainda frágeis do ponto de vista ambiental, acabam por não resolver a situação estabelecida, mas apenas minimizar os danos já causados (Rebelo, 2010; Viana, 2011, Cap.XIV). Esse constitui o principal mecanismo de negação da lógica preservacionista da lei em vigor, como se ela fora equivocada.

Conforme foi amplamente denunciado por vários pesquisadores e movimentos ambientalistas, a introdução do referido conceito criou uma anistia de passivo ambiental. Quer dizer, a definição de "Área Rural Consolidada" possibilita legitimar desmatamentos ilegais e degradações ambientais ocorridos até julho de 2008, incluindo desrespeito às APPs e à Reserva Legal.

Além dos danos presentes, a inserção desse conceito cria um sério risco ou precedente de uma prática legislativa de "revisão periódica" para legalizar o ilegal. A inclusão do $\S 3^{\circ}$, do art. $8^{\circ}$, no relatório aprovado nas Comissões de Agricultura e Reforma Agrária (CRA) e de Ciência e Tecnologia (CCT) do Senado é a materialização desse precedente. ${ }^{7}$ Embora afirme que "[...] não haverá, em qualquer hipótese, nenhum direito à regularização de futuras intervenções ou supres-

${ }^{7}$ No texto sancionado da Lei 12.651, de 2012, esse dispositivo passou a ser o $\$ 4^{\circ}$, do art. $8^{\circ}$. 
sões de vegetação nativa, além dos previstos nesta Lei” (Silveira, 2011, art. $8^{\circ}$, §3º), esse artigo acaba por assumir que a atual revisão está regularizando situações irregulares. Mais do que impedir que isso aconteça novamente - afinal, a Lei em vigor já deveria ser o suficiente para evitar isso -, ao se colocar esse artigo, explicita-se a possibilidade de que novas revisões como essa aconteçam no futuro.

O conceito Área Rural Consolidada é o eixo de todo o Programa de Regularização Ambiental Rural (PRA), proposto no texto aprovado na Câmara (Rebelo, 2011). Presente em vários dispositivos do texto em discussão, sua aplicação representa a materialização da anistia, pois o que está “consolidado” não é passível de sanção, mesmo que esteja fora dos parâmetros legais em vigor. Além disso, ele irá esvaziar o mando constitucional referente ao cumprimento da função social da propriedade rural que, entre outras, consiste na utilização adequada dos recursos naturais e na preservação do meio ambiente. ${ }^{8}$

Nessa lógica, as propostas de alteração nos parâmetros relativos à Área de Preservação Permanente (APP) e à Reserva Legal tiveram, grosso modo, dois enfoques: a) a máxima de que a lei deve se adequar à situação vigente de ilegalidades no país, ou seja, regularizar irregularidades; b) a flexibilização dos parâmetros de preservação para o futuro. Os dois enfoques flertam com o perigo de se ter, legalmente, uma situação de desproteção ambiental.

Os esforços feitos no Senado não resolveram os problemas do texto originário da Câmara (Rebelo, 2010), a exemplo da exigência de recomposição de áreas desmatadas, que foi sumariamente rejeitada no texto final aprovado pelos Deputados e encaminhado à sanção presidencial, demons-

${ }^{8}$ Essa noção retira qualquer possibilidade de desapropriação de imóvel para fins de reforma agrária que não estiver cumprindo um dos dispositivos constitucionais dessa função, que é o respeito e a preservação do meio ambiente (Lima e Fernandes, 2011). Além disso, a noção de "consolidada" amplia a área a ser indenizada para fins de reforma agrária, pois Reserva Legal ou APP em uso serão computadas como terras passíveis de indenização, o que não consta da atual legislação, dificultando a desapropriação com a elevação do valor das propriedades devido à inclusão de APP e Reserva Legal (Benjamin, 2011). trando nenhuma preocupação com a preservação ambiental. ${ }^{9}$ Independentemente do resultado final, fica evidente a postura na qual o discurso ambiental, embora fartamente usado por todos os setores, não se reflete nas propostas nem nos textos aprovados que alteraram o Código Florestal.

As tentativas de diminuição das Áreas de Preservação Permanente são visíveis em diferentes níveis. Desde propostas de diminuição dos limites (metragem) das APPs ripárias, passando pela subtração, na definição, de áreas que eram consideradas de proteção permanente até a admissão de atividades agrícolas que, antes, não eram possíveis nessas áreas (Rebelo, 2011, art. $8^{\circ}$; Viana, 2011, art.62). ${ }^{10}$

A proposta de diminuição da faixa de mata ciliar (APP ripária) foi cogitada durante toda a discussão na Câmara, desde a Comissão Especial criada em setembro de 2009. A tentativa de incluir nova faixa para os rios de até cinco metros de largura ganhou destaque, pois a intenção era baixar a faixa de APP de 30 para quinze metros (Rebelo, 2010a, art. 4\% , I, a). No texto aprovado na Câmara dos Deputados e também no Senado, foi retirado o limite de quinze metros de mata ciliar para cursos d'água de até cinco metros de largura e retomadas as faixas definidas na Lei de 1964 (de trinta metros de mata para rios com menos de dez metros de largura). No entanto, o texto abriu a possibilidade de não recomposição dos trinta metros, passando a exigir apenas quinze metros para rios de até dez metros de largura (Rebelo, 2010, art. 35; Viana, 2011, art. $62, \S 4^{\circ}$ ), ampliando a possibilidade real de redução de matas ciliares para esses rios em todas as propriedades, independentemente

\footnotetext{
${ }^{9}$ A Medida Provisória 571/2012, em seu art. 61-A, reinseriu regras para recomposição de APP. $\mathrm{O}$ artigo, em substituiç̃o ao art. 61 vetado pela Presidenta, procura equacionar um dos pontos mais polêmicos em toda a discussão da matéria no Congresso Nacional.

${ }^{10}$ A mais recente tentativa de diminuir as APPs foi a aprovação da Emenda 183 (de autoria do Dep. Giovanne Queiroz - PDT/PA) à MP 571, que incluiu o termo "perene" ao texto do inciso I, do art. $4^{\circ}$, da Lei 12.651/2012, significando que as APPs ripárias deixam de ser exigidas para cursos d'água intermitentes, portanto, deixa de ser protegida grande parte da rede hidrológica brasileira, sentenciando os rios intermitentes à morte, justamente, os mais vulneráveis e que requerem maior proteção.
} 
do tamanho do imóvel.

O texto aprovado no Senado separou as disposições permanentes das transitórias e estabeleceu a possibilidade de recomposição restrita às áreas ditas consolidadas até 2008. Diferentemente do texto da Câmara, estabeleceu também a exigência de recomposição para rios acima de dez metros de largura (Viana, 2011, art.62, §§ $5^{\circ}$ e $7^{\circ}$ ). No entanto, as regras ficaram confusas, pois, em primeiro lugar, exigem a recomposição das faixas marginais, tomando como referência a metade da largura do curso d'água. Em segundo lugar, estabelecem limites de recomposição que não podem ser inferiores a trinta metros nem superiores a cem metros de mata ciliar. De acordo com a primeira parte da regra, rios acima de $600 \mathrm{~m}$ de largura teriam APP de $300 \mathrm{~m}$, mas com a faixa estabelecida de recomposição. Isso cai para $1 / 3$, ou seja, apenas $100 \mathrm{~m}$ de APP, reduzindo a mata para apenas $20 \%$ do exigido inicialmente na Lei de 1965, então em vigor (Viana, 2011, art.4º).

No texto do Senado, a flexibilização passou a ser, prioritariamente, para as áreas consolidadas, diferença estrutural significativa em relação ao texto inicial da Câmara, que previa isso de forma mais abrangente. A estrutura aprovada no Senado permanece na Lei 12.651/2012, recentemente sancionada (Cap.XIII), sendo que a novidade foi dada pela Medida Provisória que propõe outras regras para a recomposição. ${ }^{11}$

No entanto, a insegurança permanece, uma vez que o conceito de área rural consolidada continua inalterado em sua essência. A permanência do termo agrossilvopastoril, na definição, continuou no Senado, no texto final da Câmara e no texto sancionado, consolidando, assim, todas as atividades atualmente existentes em APPs, para todas as propriedades, independentemente do seu tamanho, chancelando uma ocupação antes não

11 A exigência de recomposição de APP ripária foi estabelecida para todas as propriedades e não só para aquelas ao longo de rios com até 10 metros de largura, sendo que as faixas (de cinco metros, oito metros e quinze metros) não foram estabelecidas com base na largura do rio, e sim em relação à extensão do imóvel (até um Módulo Fiscal, entre um e dois Módulos, e entre dois e quatro Módulos, respectivamente), com outras regras para imóveis acima de quatro Módulos Fiscais (MP 571/2012, art.61-A). permitida nessas áreas de preservação (Rebelo, 2010, art. $8^{\circ}$; Viana, 2011, art. 62, §4 , Lei 12.651/ 2012, art. $3^{\circ}$, inciso IV; MP 571, art.61-A).

Outro aspecto importante dos mecanismos usados para a redução de Áreas de Preservação Permanente de margem de rios é o referencial para o cálculo de extensão de mata ciliar. Pela lei em vigor, o cálculo é feito a partir do nível mais alto do curso d'água (Resolução Conama 303/2002, art. $2^{\circ}$, I), ou seja, o referencial é o nível que o rio chega em período de cheia. Tanto na Câmara quanto no Senado, a APP ripária passa a ser medida a partir da "borda da calha do leito regular”, portanto, o rio com sua vazão normal. Com essa mudança de referencial, há uma redução considerável da área legalmente protegida, o que pode significar uma redução efetiva da dimensão da área de preservação de curso d'água em todo o país (Araújo; Juras, 2010), além da desproteção das áreas úmidas, como, por exemplo, as várzeas, os igarapés e os mangues (Piedade et. al., 2012). ${ }^{12}$

O caso das várzeas e dos mangues (art. $4^{\circ}$, $\S 3^{\circ}$ ), assim como os salgados (art. $3^{\circ}, \mathrm{XV}$ ) e os apicuns (art. $3^{\circ}, \mathrm{XIV}$ ), são exemplos também do fatiamento da definição de APPs no texto aprovado na Câmara dos Deputados (Rebelo, 2010). As mudanças na definição $\left(\operatorname{art} .3^{\circ}\right)$ teriam implicações diretas nos dispositivos que tratam da possibilidade de intervenção ou supressão de vegetação em APPs. ${ }^{13}$ A tentativa, no Senado, foi de reverter algumas situações, como, por exemplo, a inclusão da várzea novamente como APP, mas a proteção aos manguezais ainda continua frágil. Defendido por biólogos, os apicuns e salgados constituem parte integrante do mangue e são muito cobiçados por donos de empreendimentos de carcinicultura.

No texto aprovado no Senado, as ativida-

${ }^{12}$ Isso representa uma mudança nas regras para o futuro, contrariando a suposta lógica de flexibilizar a compensação de perdas ambientais apenas relativas ao passado.

${ }^{13}$ Ao aprovar a Emenda Global de Plenário n ${ }^{\circ} 186$ (texto do relator apresentado em plenário), no dia 24/05/2011, o Plenário da Câmara aprovou também a Emenda n ${ }^{\circ} 164$, que deu nova redação ao art. $8^{\circ}$ da Emenda Global, flexibilizando as possibilidades de intervenção ou supressão em áreas de preservação permanente. 
des já existentes nessas áreas entraram no rol das situações consolidadas. Não satisfeitos, parlamentares pressionaram para que o uso dessas áreas também fosse flexibilizado para o futuro, sendo criado um capítulo específico para tratar do assunto. O resultado é que a atividade de carcinicultura passou a ser permitida em $10 \%$ no bioma amazônico e 35\% nos demais biomas, além das áreas já consolidadas (Viana, 2011, cap. IV, § $\left.1^{\circ}\right) .{ }^{14}$ Possibilitar a utilização de mangue, em hipóteses antes não permitidas, pode significar a ocupação desse importante ecossistema com consequências desastrosas (Schaeffer-Novelli et al., 2012). Novamente, o argumento da lei que abarca as situações de irregularidade existentes reina sobre o argumento ambiental, corroborando também outro equívoco, ou seja, a flexibilização da proteção para situações futuras.

Os mecanismos de redução de APPs foram aplicados em várias e diferentes situações. Portanto, mesmo mantendo os parâmetros vigentes, as excepcionalidades resultam em flexibilizações e fragilidades no sistema de proteção. Para a promotora Cristina Godoy de Araujo Freitas, as propostas para reduzir a proteção das Áreas de Preservação Permanente ferem o direito fundamental ao meio ambiente ecologicamente equilibrado, garantido pela Constituição Federal em seu art. 225 (Freitas, 2011). Mesmo com previsão de mecanismo de recuperação, há possibilidades reais de diminuição dessas áreas.

Todo esforço para regularizar o desmatamento nessas áreas pode significar um ganho marginal para os proprietários da terra, se comparado ao gigantesco ônus para a sociedade como um todo (ABC; SBPC, 2011). Principalmente em se tratando de APPs de margem de rios, uma área de preservação que tem como função principal a manutenção dos cursos d'água. A manutenção dos cursos d'água deveria ser a principal preocupação no contexto da segurança alimen-

${ }^{14}$ O Dep. Antônio Balhmann (PSB/CE), apoiado pela Frente Parlamentar da Agropecuária, apresentou a Emenda 266 MP, alterando os limites de $10 \%$ para $20 \%$ no bioma amazônico e de $35 \%$ para $80 \%$ no restante do país, demonstrando total falta de compromisso com a preservação dos manguezais em favor de ganhos na carcinicultura. tar, conforme veremos adiante.

As discussões em torno da permanência e dos percentuais exigidos de Reserva Legal tomaram grande parte dos debates sobre o Código Florestal. O Código atual estabelece que a vegetação da Reserva Legal não pode ser suprimida, podendo apenas ser utilizada sob regime de manejo florestal sustentável (art.16, $\S 2^{\circ}$ ), ${ }^{15}$ definindo também os percentuais da fração do imóvel destinada à Reserva Legal (art.16).

A diferença na discussão sobre Reserva Legal e Áreas de Preservação Permanente foi marcada pela explícita vontade dos representantes do setor produtivo de acabar com esse instituto jurídico. Diferentemente da APP, cujo discurso da preservação ambiental casava bem com a proteção de cursos d'água para a produção - mesmo que isso não tenha impedido as tentativas de diminuição das APPs -, para a Reserva Legal esse discurso nem foi cogitado. Ao contrário, em vários momentos, a Reserva Legal foi tratada como empecilho à produção, como mera "finalidade paisagística" ou como um "corpo estranho" na propriedade rural (Abreu, 2010), que afeta o lucro.

Com o objetivo de acabar com esse instrumento jurídico, os representantes do setor patronal fizeram várias propostas, e os textos aprovados demonstram isso. A estratégia primeira foi a não exigência de Reserva Legal para as pequenas propriedades ou posses rurais, definidas como área de até quatro módulos fiscais (Rebelo, 2010a, art.13, caput). A segunda foi utilizar o mecanismo de não exigência da recomposição de áreas desmatadas para esses imóveis (Rebelo, 2010, art.13, §7 $7^{\circ}$. A terceira proposta foi a não exigência de recomposição restrita a imóveis com área de até quatro módulos, mas estendida às médias e grandes propriedades (Rebelo, 2010a, art.28).

De fato, tanto na Câmara quanto no Senado, a possibilidade de não exigência da recomposição de Reserva Legal para imóveis rurais com até quatro módulos fiscais permaneceu. $\mathrm{O}$ único

${ }^{15}$ Redação dada pela Medida Provisória nº 2.166-67, de 2001. 
ajuste no Senado foi o de estabelecer que os quatro módulos sejam aqueles existentes em julho de 2008, cuidado para evitar que fracionamentos posteriores desencadeassem o surgimento de novos imóveis com quatro módulos, para se valer da flexibilização (Viana, 2011, art.69).

No Senado, houve embates para restringir essa flexibilização à agricultura familiar. Essa e outras reivindicações resultaram na inclusão da definição de agricultura familiar nos termos da Lei 11.326, de 2006, para caracterizar a pequena propriedade ou posse rural familiar (Lima; Fernandes; Intini, 2012, p.3), ${ }^{16}$ e na criação de um capítulo específico para esse segmento social (Viana, 2011, cap.XIII). No entanto, o texto do Senado ampliou o conceito quando estendeu “... o tratamento dispensado aos imóveis a que se refere o inciso $\mathrm{V}$ (definição de agricultura familiar) desse artigo às propriedades e posses rurais com até quatro módulos fiscais que desenvolvam atividades agrossilvipastoris" (Viana, 2011, art.3오 § único). Além de ampliar o conceito, o esforço para evitar uma flexibilização generalizada ficou comprometido, pois todas as propriedades até quatro módulos, familiares ou não, passam a ter o mesmo tratamento.

É importante observar que há muitas propriedades pequenas e médias ou imóveis que não podem ser definidos como de agricultura familiar a partir dos critérios da Lei $\mathrm{n}^{\mathrm{O}} 11.326$, de 2006 (Lima; Fernandes; Intini, 2012, p.3). Segundo essa lei, a classificação de produtor familiar exige o cumprimento de diversos requisitos, especialmente o trabalho em regime familiar, mesmo detendo área igual ou inferior a quatro módulos. Além disso, muitos imóveis, com área inferior a quatro módulos, não podem ser classificados como de pequenos agricultores, pois são imóveis de empresas com grandes empreendimentos e uso de mão de obra assalariada, ou mesmo utilizados como chácaras e áreas de lazer.

${ }^{16}$ Segundo esses autores, um avanço importante no texto do Senado foi a caracterização da agricultura familiar "como atividade de interesse social e de baixo impacto ambiental" e a inclusão de terras indígenas demarcadas, áreas tituladas de povos e comunidades tradicionais e projetos de reforma agrária (Lima; Fernandes; Intini, 2012, p. 3).
Nesse sentido, se tomarmos como parâmetro o tamanho médio dos imóveis, a esmagadora maioria de áreas não familiares será beneficiada com essa flexibilização, pois a concentração fundiária coloca poucos imóveis acima dos quatro módulos, conforme veremos adiante. De acordo com dados do Censo Agropecuário da agricultura familiar, “... a área média dos estabelecimentos familiares era de 18,37 hectares, e a dos não familiares, de 309,18 hectares" (IBGE, 2009, p.19). Consequentemente, na Amazônia Legal, onde o módulo corresponde a uma área entre 80 a 120 hectares, em média, a flexibilização na recomposição de Reserva Legal irá beneficiar muitos, além dos agricultores familiares.

A não exigência de recomposição é outra maneira de consolidar apropriações indevidas dessas áreas. O texto admite como Reserva Legal a vegetação nativa existente até julho de 2008, sem nem o cuidado de exigir um percentual mínimo como Reserva Legal. Portanto, não importa quão próxima de zero seja a vegetação existente, ela será legalizada. Essa isenção não é apenas para aqueles que, sob a égide de outros parâmetros legais que definiam percentuais menores, desmataram mais do que estabelecia a Lei em vigor, mas beneficia todos que desmataram até 2008 .

Embora em estados como Santa Catariana e Espírito Santo, cujas propriedades familiares representam, respectivamente, 90\% e 97\% do total de propriedades (Freitas, 2011), não é nessas regiões que se encontra o maior passivo de Reserva Legal. A partir da definição dos módulos fiscais, dados do Censo Agropecuário de 2006 (IBGE, 2009a) mostram que as propriedades com até quatro módulos abrangem maior área nas regiões Amazônica e em grande parte do Centro-Oeste. Admitir a isenção de recomposição de Reserva Legal consiste em abrir mão de um montante significativo de cobertura vegetal, pois cerca de 30 milhões de hectares ficariam livres de recuperação em todo o país, e mais da metade, 18 milhões de hectares, só na Amazônia (IPEA, 2011, p.9).

O discurso de beneficiar os pequenos ou 
a agricultura familiar é facilmente extrapolado para o argumento de isonomia. A tentativa de exigir a mesma isenção para os médios e os grandes proprietários sempre esteve presente. A primeira proposta fez parte do texto aprovado na Comissão Especial e consistia na explícita exigência de recomposição ou compensação da Reserva Legal em relação à área que "exceder a quatro módulos fiscais do imóvel” (Rebelo, 2010a, art.28). Se essa medida fosse adotada, significaria a não recuperação de cerca de 50 milhões de hectares (IPEA, 2011, p.9).

Outro mecanismo utilizado na linha de acabar com a Reserva Legal é permitir o cômputo de APP em Reserva Legal para todos os tipos de propriedade. O Código em vigor define critérios para garantir a existência das duas áreas, uma vez que elas têm funções ecossistêmicas diferentes. O cômputo generalizado abre a possibilidade de não existência efetiva de Reserva Legal e manutenção apenas de APP. Do ponto de vista da reabilitação dos processos ecológicos, de conservação da biodiversidade e do abrigo e proteção da fauna e da flora, isso é um equívoco (ABC; SBPC, 2012).

Para reforçar o argumento de que a Reserva Legal não tem papel importante dentro da propriedade, sua função ecológica foi transferida para os parques e Unidades de Conservação (Abreu, 2011). No entanto, dados da SBPC e ABC comprovam que as Reservas Legais, juntamente com os parques e unidades de conservação, são complementares para garantir o equilíbrio ambiental, pois elas têm o papel de corredores ecológicos. Além disso, nos casos de biomas onde a área ocupada por unidades de conservação não representa parcela significativa e não existe área física para a criação de novas, as Reservas Legais são essenciais para conservação da biodiversidade (IPEA, 2011, p.14). O equilíbrio ecológico é condicionante para garantir os recursos naturais necessários à produção de alimentos. Se isso é colocado em xeque, como esperar que o aumento da produção seja garantido?

Ao que tudo indica, as defesas incondicionais da mudança dos parâmetros da Reserva
Legal estão menos preocupadas em aumentar a disponibilidade de terras para cultivo, e mais em garantir as áreas já apropriadas ilegalmente. De fato, se a questão fosse só o aumento de área para plantar, então o debate seria resolvido com a recuperação de áreas degradadas, ou com a conversão de áreas de pastagem para lavouras. Estima-se que, em razão do uso inadequado do solo, existem 61 milhões de hectares de terras degradadas no Brasil, que poderiam ser recuperadas e usadas na produção de alimentos (ABC; SBPC, 2011). Portanto, dados disponíveis e projeções indicam que é possível ampliar áreas resgatando passivos ambientais sem prejudicar a produção e a oferta de alimentos.

\section{MUDANÇAS DO CÓDIGO E A FUNÇÃO SOCIOAMBIENTALDA TERRA}

Empurrada pelos ventos democratizantes dos anos 1980, a Constituição Brasileira de 1988 "importou" a noção de função social da propriedade do Estatuto da Terra (Marés, 2002), estabelecendo um limite à histórica noção de propriedade absoluta no Brasil. Mantendo sua lógica liberal, a Carta Magna colocou, entre os "direitos e garantias fundamentais" (art. $5^{\circ}$ ), o direito de propriedade (Inciso XXII). Mas, no inciso seguinte (XXIII), estabeleceu também que "a propriedade atenderá a sua função social” (Brasil, 2006).

É importante observar que, na lógica constitucional, o cumprimento da função social não é uma exigência apenas na propriedade da terra, mas de toda e qualquer propriedade. Essa mesma exigência se repete nos princípios da ordem econômica e financeira (art.170, inciso III), sendo que o mandado constitucional da função social da terra aparece no art. 186, precisamente onde o conteúdo dessa função traz elementos concretos no texto constitucional (Brasil, 2006). ${ }^{17}$

Diferentemente do que apregoam alguns, em

${ }^{17}$ Para maiores detalhes em relação ao debate sobre a reforma agrária durante o processo Constituinte, ver, por exen
plo, Silva (1989); Souza e Sauer (2009); Russo (2009). 
especial a Bancada Ruralista e os representantes do setor patronal rural no Parlamento, a exigência de cumprimento da função social estabelece limites, mas não questiona a propriedade. Estabelece limites e critérios ao seu uso, mas não rompe ou destrói a noção e o direito de propriedade. Ou melhor, se a interpretação do texto constitucional é que "[...] a função social é relativa ao bem e ao seu uso, e não ao direito” (Marés, 2002, p.116), o resultado lógico seria que não há propriedade (ou direito de propriedade) sem o cumprimento de sua função social, pois se

[...] se diz que a função social é da terra (objeto do direito) e não da propriedade (o próprio direito) ou do proprietário (titular do direito), se está afirmando que a terra tem uma função a cumprir independentemente do título de propriedade que possam lhe outorgar os seres humanos em sociedade (Marés, 2002, p.113).

No entanto, essa não é a interpretação e a consequente prática jurídica correntes nos casos em que há violação da função social da terra. A reafirmação da propriedade (na prática jurídica e nas políticas governamentais) é baseada, fundamentalmente, na previsão constitucional de indenização ("prévia e justa"18) nos casos de desapropriação (art.184, caput), sendo que o direito (de propriedade) é garantido independentemente de a motivação para limitar esse direito ser a violação da função social da terra.

Essa desapropriação deve ser feita (uma obrigação do Estado, segundo a Constituição, art. 194, caput) quando o imóvel (ou propriedade rural) não cumpre a função social, a qual tem os seguintes requisitos nos termos dos quatro incisos do artigo 186:

I - aproveitamento racional e adequado; II - utilização adequada dos recursos naturais disponíveis e preservação do meio ambiente; III - observância das disposições que regulam as relações de trabalho; IV - exploração que favoreça o bem-

\footnotetext{
${ }^{18}$ Certamente, na concepção de que a terra (e não a propriedade) deve cumprir a função social, uma violação desse preceito constitucional resultaria na necessária definição do que seria “justo", e não simplesmente o pagamento da terra, com a emissão de títulos públicos, em valores de mercado.
}

estar dos proprietários e dos trabalhadores (Brasil, 2006, p.124).

Há controvérsias se esses requisitos constitucionais, estabelecendo condições ao direito de propriedade, devem ser entendidos como avanços, por exemplo, em relação ao que já estabelecia o Estatuto da Terra, de $1964 .{ }^{19}$ Segundo Marés (2002, p.116), “... em um sistema que tem a propriedade privada como sustentáculo, essa qualificação deve ser considerada avançada, porque faz prevalecer a condição à propriedade, à vida ao direito individual".

Sendo assim, é fundamental a concepção de que a terra deve cumprir não só uma função social, mas também uma função ambiental. Consequentemente, os termos constitucionais do artigo 186 transcendem as interpretações correntes, estabelecendo vários requisitos socioambientais, além do uso econômico-produtivo da terra, amplamente utilizado como sinônimo de "uso racional e adequado", como veremos a seguir. Claramente, o inciso II estabelece que a função social é composta também pela “[...] utilização adequada dos recursos naturais disponíveis e preservação do meio ambiente" (Brasil, 2006, p.124).

Conforme já mencionado, não apenas a terra ou o imóvel rural deve cumprir função social, mas toda e qualquer propriedade (art. $5^{\circ}$, cap.XXIII). Associado a essa função socioambiental, o texto constitucional estabeleceu o meio ambiente como um bem comum, um "bem de uso comum do povo" (art.225, caput), “[...] impondo-se ao poder público e à coletividade o dever de defendêlo e preservá-lo para as presentes e futuras gerações" (Brasil, 2006, p.140). Sendo um bem de todas as pessoas, o mandado constitucional tornou uma obrigação ou dever, não só do poder público (governos), mas também da coletividade, não apenas preservar e sim também defender o

${ }^{19}$ Russo (2009, p.180) chama a atenção para o fato de que a emenda popular da reforma agrária introduzia um novo instituto jurídico sobre a função social do Estatuto da Terra, de 1964, ou seja, o estabelecimento de um limite máximo de propriedade, o que não foi aprovado no texto final da Constituição. 
meio ambiente, reforçando a função socioambiental da terra.

Na contramão desse mandado constitucional, a senadora e presidente da Confederação da Agricultura do Brasil (CNA), Kátia Abreu, em reunião da Comissão de Constituição e Justiça do Senado que apreciou a constitucionalidade do projeto de lei em tela, retomou o art. 225 da Constituição, mas deu uma interpretação, no mínimo, estranha. De acordo com Abreu, o meio ambiente é um "[...] bem coletivo, mas não pode haver um ônus individual”, consequentemente, seria inconstitucional "[...] impor o ônus individual de uma Reserva Legal e de uma APP aos agricultores sem indenização de suas propriedades rurais" (Abreu, 2011).

Em primeiro lugar, esse argumento reduz a noção de bem comum aos espaços definidos como espaços públicos (parques, florestas nacionais etc.). Em completa oposição ao espírito constitucional, essa interpretação reduz o cuidado com o meio ambiente aos espaços públicos, destruindo a noção de "bem comum”, pois ação privada (ou individual) de preservação só se faria mediante indenização ou compensação financeira. De acordo com palavras da própria senadora, “[...] nos Estados Unidos criam-se quantos parques nacionais se façam necessários, e ninguém tem nada a objetar, porque desapropria-se, indenizam-se os produtores e formamse os parques à vontade” (Abreu, 2011).

Em segundo lugar, lança mão de uma dicotomia completa entre o coletivo (constituição de um bem é de todas as pessoas) e o individual (ausência de responsabilidades ou obrigações das pessoas em relação ao bem comum), resultando em uma coletividade abstrata e sem sujeitos (de direitos ou de obrigações) concretos. Essa dicotomia corrobora e aprofunda o já histórico modelo agropecuário baseado em um “capitalismo rentista” (Martins, 1994), ou seja, em processos de acumulação privada (monopólio da terra, apropriação das riquezas do campo), através de subsídios públicos e incentivos fiscais governamentais (Martins, 1989). Nos ter- mos de Paulino (2012, p.46), a acumulação de riquezas no campo vem sendo "[...] proporcionada pelo acesso gratuito a bens como madeira, água e solo fértil, entre outros elementos da biodiversidade, mediado pelo trabalho precarizado", sem qualquer retorno ao conjunto da sociedade, à coletividade.

Em terceiro lugar, e talvez o mais fundamental: na lógica da senadora, como representante do setor patronal rural, não há qualquer reconhecimento da própria terra como um bem comum, um bem da sociedade. Mesmo em uma lógica capitalista, como um bem da natureza, como um bem finito, o uso da terra (privado ou individual), bem como sua transformação em mercadoria, deve reverter em algum benefício para o conjunto da sociedade (Paulino, 2012). Essa é a base (filosófica) para a criação, por exemplo, do Imposto sobre a Propriedade Territorial Rural (ITR), estabelecido a partir do Estatuto da Terra, em 1964, o qual deveria ser um instrumento capaz de impedir a posse de terras ociosas. ${ }^{20}$ É bem verdade que esse ITR não é pago (os níveis de evasão fiscal são altíssimos) pela esmagadora maioria dos grandes proprietários de terras. ${ }^{21}$ No entanto, essa inadimplência não invalida a lógica pressuposta no estabelecimento de um tributo ao uso da terra.

No contexto dos embates sobre o Código Florestal, os argumentos em defesa de uma desobrigação de proteger e preservar o meio ambiente, no entanto, não se restringem apenas à reafirmação do direito (individual e absoluto) da propriedade da terra (e a consequente indenização de qualquer processo de conservação que transcenda os interesses privados). Diferentemen-

\footnotetext{
${ }^{20}$ Segundo o Estatuto da Terra (Lei 4.504, de 30 de novembro de 1964), o ITR deveria ser progressivo como um instrumento para "incentivar a política de desenvolvimento rural” (art. 47, caput); “[...] desestimular os que exercem o direito de propriedade sem observância da função social e econômica da terra" (Inciso I) e "[...] estimular a racionalização da atividade agropecuária dentro dos princípios de conservação dos recursos naturais renováveis.“ (inciso II).

${ }^{21}$ A reforma do ITR, em 1996, não surtiu o efeito desejado de acoplar esse instrumento de política fiscal ao programa de reforma agrária, reforçando a necessidade de um uso racional e produtivo da terra, pois, segundo estimativa de Sabbato (2008, p.121), a evasão fiscal do ITR alcançava $90,3 \%$ em 1997, o que não se alterou significativamente
} nos anos seguintes. 
te de um bem comum, um lugar de vida (noção corrente para a definição de território ${ }^{22}$ ), terra é, explícita ou implicitamente, sempre e exclusivamente, associada à categoria de meio (e lugar) de produção. Essa perspectiva, como meio de produção e mercadoria, autoriza a senadora a afirmar que Reserva Legal e APP são ônus porque retiram “[...] competitividade dos agricultores em comparação a outros países do mundo" (Abreu, 2011).

A noção da terra como propriedade privada (e mercadoria) não é tão antiga, pois remonta à constituição do Estado moderno, a partir do mercantilismo, mas se aprofundou com a constituição e expansão do capitalismo (Marés, 2002). No caso brasileiro, a terra ganha status de propriedade privada apenas a partir de 1850 , com a chamada Lei de Terra, pois o regime de sesmarias garantia "apenas o direito de posse e uso" privado (Martins, 1994, p.76), sendo que "o direito de usar e o direito de ter eram separados e combinados." (Martins, 1993, p.67), pois a propriedade era do Estado. $^{23}$

Sem pretensões de fazer esse resgate histórico da transformação da terra em propriedade privada, é importante entender os processos recentes de sua redução a um simples meio de produção, o empobrecimento das lutas territoriais e, consequentemente, o empobrecimento da noção de função social, consolidando o que Martins definiu como um "economicismo empobrecedor" (1989) ou "vulgar" (1993). Recentemente, houve uma redução da noção de função social à sua dimensão econômico-produtiva, devido, basicamente, à introdução do conceito de "terra produtiva" na Constituição de 1988, como um mecanismo para bloquear avanços na luta pela terra e a garantia de direitos do povo do campo (Martins,

${ }^{22}$ Segundo termos do Decreto 6.040/2007, que instituiu "a Política Nacional de Desenvolvimento Sustentável dos Povos e Comunidades Tradicionais", o território é definido como "os espaços necessários à reprodução cultural, social e econômica dos povos e comunidades tradicionais" (art. $2^{\circ}$ ).

${ }^{23}$ Segundo Martins (1994, p.76), “[...] no regime sesmarial, o fazendeiro tinha apenas a posse formal, que podia ser objeto de venda, mas o rei, isto é, o Estado, mantinha sobre a terra a propriedade eminente, podendo arrecadar terras devolutas ou abandonadas e redistribuí-las para outras pessoas, como fora comum até o século XVIII”.
1993).

Apesar da consolidação da noção de função social, os embates parlamentares ${ }^{24}$ levaram a um texto constitucional que recepcionou a noção de "terra produtiva" (art.185, Inciso II), introduzindo "[...] uma ampla ambiguidade na definição das propriedades sujeitas à desapropriação" (Martins, 1994, p.90) para fins de reforma agrária. Mais que uma ambiguidade, esse conceito permitiu uma interpretação e uma prática que invertem totalmente o espírito constitucional. Segundo Marés, esse dispositivo tem sido interpretado às avessas, ou seja, "[...] mesmo que não cumpra a função social, a propriedade produtiva não pode ser desapropriada" (2002, p.119).

O Inciso II, do art. 185 passou a ser trava fundamental para limitar a redistribuição do acesso à terra, pois consolidou uma noção restrita de função social, resumida à sua dimensão econômica. O único critério utilizado para a desapropriação, tanto pelo Poder Executivo como pelo Judiciário, é a avaliação econômica do "uso racional" das terras como sendo ou não produtivas (Sauer, 2011). Essa avaliação puramente econômica foi consolidada na Lei 8.629, de 1993, que regulamentou os dispositivos constitucionais relativos à reforma agrária, quando estabeleceu que propriedade produtiva é "[...] aquela que, explorada econômica e racionalmente, atinge, simultaneamente, graus de utilização da terra e de eficiência na exploração" (art. $6^{\circ}$ ), sem qualquer referência ou condição ao cumprimento da função social e do uso ambientalmente adequado (Marés, 2002).

Nessa linha de raciocínio, a luta pela terra é entendida como restrita a reivindicações de acesso a um meio de produção e, por extensão, ao trabalho (Martins, 1993). Aliás, esse vínculo com o direito ao trabalho é o único na relação com

${ }^{24}$ Segundo José Gomes da Silva (1989, p.14), o debate sobre a reforma agrária foi marcado por sérios incidentes entre parlamentares e mesmo fora da Assembleia Nacional Constituinte, envolvendo "[...] escaramuças, pugilatos, sopapos e manifestações de massa, além de ter apresentado o maior número de assinaturas na fase de Emenda Popular, cerca de um milhão e duzentas mil”. 
o direito à terra por parte das populações do campo, não definidas ou classificadas como "populações tradicionais". Em outros termos, a luta pela terra não é uma luta por direitos como de moradia (um lugar para viver) ou de identidade (como camponês, produtor rural, agricultor familiar), mas apenas por produção e, no máximo, pelo direito ao trabalho como um direito humano (Sauer, 2010). O direito dos agricultores familiares camponeses não se justifica pelo direito de ser e de reprodução social (ou pela "consciência de ser", parafraseando os termos da Convenção 169 da OIT), mas apenas pelo fator produção (2011). ${ }^{25}$

A interpretação restritiva à dimensão econômica só é possível a partir da compreensão do dispositivo constitucional (art.185, Inciso II) como somente "[...] uma produtividade econômica, como rentabilidade, de uma maneira puramente economicista” (Marés, 2002, p.119), desvinculada dos demais critérios ou condições da função social. A conclusão é desastrosa, pois “[...] a propriedade considerada produtiva não sofre qualquer sanção ou restrição pelo fato de não cumprir a função social” (2002, p.119).

Na interpretação do texto constitucional, é fundamental, portanto, reafirmar o caráter socioambiental da terra e não meramente seu uso e sua exploração econômica. A função socioambiental e o "aproveitamento racional e adequado" (Inciso I do art.186) não se restringem à produção e exploração da terra. ${ }^{26}$ Aliás, é fundamental não confundir ou ter como sinônimos uso e função. Nesse sentido, Comparato (2006, p.18) é categórico ao afirmar que “[...] não é qualquer produção que serve de escudo ao proprietário rural para escapar da reforma agrá-

${ }^{25}$ A prática provocou uma distância entre as noções de terra (apenas como meio e lugar de produção) e de território (lugar da identidade, do autorreconhecimento, da ocupação histórica etc.), o que vem dando diferentes significados às lutas por terra (frequentemente vistas apenas como ocupações de terras improdutivas) e por território (resistência de populações tradicionais à invasão de suas terras). Sobre lutas territoriais e lutas por terra, ver Sauer (2010; 2011).

${ }^{26}$ Como bem lembra Marés (2002, p.125) “[...] o uso da terra pode ser intenso, gerando grande renda a seu proprietário, às vezes pode até ser muito rentável ao mesmo tempo em que não cumpre a função social”. ria, mas tão-só a produção que respeita a função da propriedade, isto é, aquela que satisfaz todas as exigências expressas no art. 186".

Conforme já mencionado, a criação e regulamentação da Reserva Legal (ou mesmo das Áreas de Preservação Permanente) estão em sintonia com a noção da necessidade de cumprir a função socioambiental da terra. Entre outras razões ambientais e sociais, essas reservas prestam "serviços ecossistêmicos" ao conjunto da sociedade, mas também representam a "sustentabilidade dos sistemas de produção” nos imóveis rurais como, por exemplo, regulação hidrológica e atmosférica, controle da erosão, serviços da biodiversidade (polinização, entre outros) (ABC; SBPC, 2011, p.52). Consequentemente, não faz qualquer sentido argumentos como os já mencionados de que “[...] a Reserva Legal é um bem coletivo, com ônus individual. Amplia-se a APP, amplia-se a Reserva Legal como um bem coletivo, mas o ônus é individual" (Abreu, 2011).

Desde o sistema sesmarial, passando pelo Estatuto da Terra e, finalmente, consolidada na Constituição de 1988, a lógica é que a terra deve ser usada, deve ser aproveitada como parte de sua função social. Esse uso e aproveitamento devem evitar práticas antissociais e ilegais, como a posse de áreas de terra como reserva de valor e especulação. No entanto, esse uso deve ser adequado, evitando-se confundir produção, exploração e rentabilidade com função social. Consequentemente, a noção de produtividade não se restringe ao grau de utilização, pois o uso "racional e adequado" da terra "[...] não pode ser no sentido de esgotar a possibilidade de renovar a vida, de transformá-la a ponto de esterilizá-la" (Marés, 2002, p.125), como, por exemplo, ações que destroem a natureza, desrespeitam as áreas de preservação (desmatamento de matas ciliares e de encostas de morros etc.), abusam de venenos (poluição das águas e contaminação do solo) e outras práticas ambientalmente insustentáveis.

Precisamente essa confusão entre uso e função, reduzindo a função socioambiental da terra à sua dimensão econômico-produtiva, 
norteou as mudanças propostas para o Código Florestal. E, em uma lógica eivada de um pensamento dito moderno, que contrapõe natureza e civilização, reafirma o uso da terra restrito à exploração e rentabilidade da produção, fazendo da natureza "inimiga da produção" e do uso adequado da terra. Segundo termos do próprio relator na Câmara,

A maior ameaça ao grande produtor é a elevação de custos de produção imposta pela legislação ambiental e florestal na realização de obras, contratação de escritórios de advocacia e renúncia de áreas destinadas à produção. Ao fim e ao cabo, a legislação ambiental funciona como uma verdadeira sobrecarga tributária, elevando o custo final do produto. (Rebelo, 2010, p.6 - ênfases nossas).

Nessa lógica, a defesa incondicional da "ampliação da produção brasileira" e maior capacidade competitiva devem incluir, "[...] além dos ganhos de produtividade, disponibilidade de terras" (Rebelo, 2010, p.19 - ênfases nossas). Essa disponibilidade, no entanto, deve ser obtida pela flexibilização das regras ambientais, especialmente para permitir uma maior ocupação de terras na fronteira agrícola como, por exemplo, a proposta de reduzir a Reserva Legal de $80 \%$ para $50 \%$ das terras na Amazônia, ou a não exigência de Reserva Legal para imóveis até quatro módulos (Rebelo, 2010a), e não pela melhoria da produtividade animal ou pela recomposição de áreas degradadas (ABC; SPBC, 2011), entre outras medidas ambiental e economicamente mais sustentáveis.

Segundo dados do Censo Agropecuário de 2006, quase metade dos 329,9 milhões de hectares, ou seja, 48,1\% da área total dos imóveis rurais são destinados à pecuária de corte (IBGE, 2009). Além de ser uma área 2,7 vezes maior do que a destinada às lavouras, que abarca 59,8 milhões de hectares, os 158,8 milhões de hectares destinados à pecuária possuem índices baixíssimos de aproveitamento, pois “[...] a taxa de lotação das pastagens ainda é baixa, cerca de 1 cabeça/ha" (ABC; SPBC, 2011, p.32).

Segundo estudos da SPBC e da ABC (2011), há várias opções técnicas disponíveis para dimi- nuir, de forma acentuada a demanda por terra. Segundo o estudo, “[...] o potencial representado pela liberação e pela recuperação de áreas degradadas de pastagem seria suficiente para acomodar o mais ambicioso dos cenários de crescimento da agropecuária” (ABC; SPBC, 2011, p. 36) e melhorar o cumprimento da função socioambiental da terra. No entanto, essa não é a intenção e o objetivo da defesa das mudanças no Código Florestal, como veremos a seguir.

\section{CONCENTRAÇÃO FUNDIÁRIA: insegurança alimentar e insustentabilidade ambiental}

Não são novas as reflexões sobre implicações da concentração da propriedade da terra, especialmente na perpetuação da pobreza e na destruição ambiental no meio rural brasileiro. $\mathrm{O}$ relatório final da III Conferência Nacional de Segurança Alimentar e Nutricional, ao afirmar que "[...] a concentração fundiária e a morosidade na implantação da reforma agrária [...]" constituem alguns dos principais obstáculos ao desenvolvimento, reafirmou também que "[...] o desenvolvimento da agricultura familiar e do agroextrativismo é estratégico para a soberania e a segurança alimentar e nutricional das populações do campo e da cidade" (CONSEA, 2007, p.17).

Na contramão dessa constatação, o Brasil possui uma estrutura fundiária altamente concentrada, uma realidade histórica confirmada pelos dados do último Censo Agropecuário, de 2006, do Instituto Brasileiro de Geografia e Estatística (IBGE). Essa concentração tem origem nos tempos coloniais, agravada pela Lei de Terras de 1850 (Martins, 1989) e, mais recentemente, a partir dos anos 1960, com a implantação da Revolução Verde, dos projetos de colonização e do atual modelo agropecuário, baseados na modernização de grandes extensões de terras, fundamentalmente com subsídios governamentais, a exemplo da isenção fiscal e de outros incentivos públicos (Martins, 1993, 1994; Sauer, 2010).

A concentração fundiária em grandes es- 
tabelecimentos agropecuários, acima de mil hectares, não se alterou nos últimos vinte anos, segundo informações dos Censos de 1985, 1995 e 2006 (Sauer; Leite, 2012). O índice de Gini, utilizado para medir a distribuição do uso da terra, manteve-se praticamente o mesmo no período, e o Brasil ainda apresenta alto grau de concentração fundiária (Brasil, 2009), expresso por 0,857, em 1995/96, e 0,856, em 2006 (Hoffmann; Ney, 2009). ${ }^{27}$

Conforme se pode observar nas Tabelas 1 (dados de 1995/1996) e 2 (dados de 2006), não houve mudanças significativas na concentração da propriedade da terra entre os dois últimos levantamentos.

Segundo dados do Censo de 2006, as propri- edades com menos de dez hectares representam mais de $47 \%$ do total de estabelecimentos, mas ocupam apenas 2,7\% da área total dos estabelecimentos rurais, ou seja, 7,8 milhões de hectares. Na outra ponta do espectro fundiário, os estabelecimentos com áreas acima de mil hectares somam apenas $0,91 \%$ do número total de estabelecimentos, mas detém mais de 43\% da área total, concentrando 146,6 milhões de hectares (Tabela 2).

Essa mesma desigualdade, evidente na distribuição do acesso à terra, está presente em outros dados no meio rural brasileiro. Em estudo sobre posse da terra e distribuição de renda, a partir de dados da Pesquisa Nacional por Amostragem a Domicílio (PNAD), do IBGE, Hoffmann e Ney (2009, p.8) constataram que
Tabela 1 - Número e área dos estabelecimentos por grupos de área total Brasil - 1996

\begin{tabular}{lcccc}
\hline $\begin{array}{c}\text { Grupos } \\
\text { de área total }\end{array}$ & $\begin{array}{c}\text { Número de } \\
\text { estabelecimentos } \\
\text { (unidades) }\end{array}$ & $\%$ & $\begin{array}{c}\text { Área dos } \\
\text { estabelecimentos } \\
\text { (hectares) }\end{array}$ & $\%$ \\
\hline Menos de 10 ha & 2.402 .374 & 49,43 & 7.882 .194 & 2,23 \\
\hline 10 a menos de 100 ha & 1.916 .487 & 39,43 & 62.693 .585 & 17,73 \\
\hline 100 a menos de 1000 ha & 469.964 & 9,67 & 123.541 .517 & 34,94 \\
\hline 1000 ha e mais & 49.358 & 1,0 & 159.493 .949 & 45,10 \\
\hline Total & $\mathbf{4 . 8 5 9 . 8 6 5}$ & & $\mathbf{3 5 3 . 6 1 1 . 2 4 6}$ & \\
\hline Fonte: IBGE, Censo Agropecuário 2006 (Brasil, 2009). & & \\
\hline
\end{tabular}

Tabela 2 - Número e área dos estabelecimentos por grupos de área total Brasil - 2006

\begin{tabular}{|c|c|c|c|c|}
\hline $\begin{array}{c}\text { Grupos } \\
\text { de área total }\end{array}$ & $\begin{array}{c}\text { Número de } \\
\text { estabelecimentos } \\
\text { (unidades) }\end{array}$ & $\%$ & $\begin{array}{c}\text { Área dos } \\
\text { estabelecimentos } \\
\text { (hectares) }\end{array}$ & $\%$ \\
\hline Menos de 10 ha & 2.477 .071 & 47,86 & 7.798 .607 & 2,36 \\
\hline 10 a menos de 100 ha & 1.971 .577 & 38,09 & 62.893 .091 & 19,06 \\
\hline 100 a menos de 1000 ha & 424.906 & 8,21 & 112.696 .478 & 34,16 \\
\hline 1000 ha e mais & 46.911 & 0,91 & 146.553 .218 & 44,42 \\
\hline Total & 5.175 .489 & & 329.941.393 & \\
\hline
\end{tabular}

Fonte: IBGE, Censo Agropecuário 2006 (Brasil, 2009).

${ }^{27}$ A concentração é favorecida tanto pela apropriacão ilegal de terras (devolutas ou áreas públicas) como pelas fragilidades cadastrais, pois tanto o Censo Agropecuário como o Sistema Nacional de Cadastro Rural do INCRA possuem fragilidades no registro dos imóveis rurais, resultando em "[...] situações de apropriação ilegal de terras devolutas ou mesmo já arrecadadas, e irregularidades no Cadastro que permitem que, em alguns casos, a área dos imóveis cadastrados supere a própria área total do estado” (MDA, 2005, p.22).
A desigualdade de renda na agricultura é caracterizada por uma proporção substancialmente maior da renda apropriada por quem está na cauda superior da distribuição do que nos demais setores. Ela é a única atividade em que a participação dos $1 \%$ mais ricos na renda total quase sempre supera a participação dos $50 \%$ mais pobres.

Essa constatação, infelizmente, corrobora e justifica dados sobre a persistência da pobreza e da fome no meio rural. De acordo com dados do "Brasil Sem Miséria”, do Governo Federal, 47\% dos brasileiros pobres estão no campo (MDS, 2011). Segundo a Câmara Interministerial de Segurança Alimentar e Nutricional, a população rural apresenta-se com “[...] $20 \%$ em insegurança alimentar leve; 9\% em insegurança alimentar moderada e 7\%, em insegurança alimentar grave” (CAISAN, 2011, p.19) em 2009.

Apesar da pobreza, da insegurança alimentar e da fome, reproduzem-se discursos ufanistas de que o Brasil deve se tornar o "celeiro do 
mundo muito em breve” (Rebelo, 2010, p. 180), ${ }^{28}$ produzindo alimentos. Para tanto, é necessário aproveitar a extensão territorial e a disponibilidade de terras, a fertilidade dos solos e as condições climáticas. As afirmações do dep. Aldo Rebelo são emblemáticas, quando escreve que

O Brasil perdeu mais de 23 milhões de hectares de agricultura e pecuária, em dez anos, para unidades de conservação, terras indígenas ou expansão urbana. Acham pouco. Querem escorraçar plantações de mais de 40 milhões de hectares e plantar mata no lugar (Rebelo, 2011, p.A3 - ênfases nossas).

A realidade de concentração da terra e das riquezas no campo, de um lado, e pobreza, exclusão e insegurança alimentar, se não fome, de outro, vem sendo historicamente alimentada por políticas públicas de incentivo à produção de commodities agrícolas (especialmente grãos) para exportação (Sauer; Leite, 2011). Segundo Delgado (2010, p.31), a partir dos anos 1980, o principal papel da agricultura na economia foi “[...] a geração de superávits crescentes na balança comercial”, transformando-a em “[...] principal instrumento para o equilíbrio da conta de transações correntes da balança de pagamentos, através de um grande estímulo governamental às exportações".

Apesar de a motivação ter sido um temor do então governo militar de "uma crise de abastecimento de alimentos", dentre as medidas adotadas para enfrentar a "crise da dívida externa”, no início dos anos 1980, está, fundamentalmente, a promoção do "[...] deslocamento de recursos dos setores produtores de bens destinados ao mercado doméstico para setores voltados às exportações" (Delgado, 2010, p.38). Essas medidas impulsionaram a já subsidiada produção de commodities agrícolas, inclusive expandindo as chamadas "fronteiras agrícolas", sendo que a

${ }^{28}$ Nesse debate, para além do ufanismo, é fundamental fazer uma clara distinção entre produção agropecuária em geral e de alimentos, pois enquanto a cana de açúcar teve "uma expansão média de 10,8\% ao ano", o cultivo de arroz "teve um decréscimo de $7,1 \%$ ao ano e a mandioca viu sua área ser reduzida a uma taxa de 1,6\% ao ano" (CAISAN, 2011, p.16). tão propalada produção de alimentos foi apenas o argumento para impulsionar os negócios agroexportadores.

Essas iniciativas governamentais são as grandes responsáveis pelo aumento da produção de commodities agrícolas para exportação, em detrimento da produção de alimentos para o mercado interno. Nos últimos vinte anos, os cultivos para exportação tiveram crescimentos significativos como, por exemplo, a soja cresceu $188 \%$ e a cana $156 \%$. No entanto, a produção de arroz cresceu $70 \%$, o trigo, $63 \%$, o feijão $56 \%$, e a mandioca não registrou crescimento algum nas últimas duas décadas (IBGE, 2009b).

Recentemente, em especial na última década, o aumento da produção de commodities levou a uma nova e vigorosa expansão da fronteira agrícola. A abertura de novas áreas, notadamente para a produção de soja, incorporou extensas áreas localizadas nos estados do Maranhão, Piauí e Tocantins (a região do "Mapito"), ou incluindo a Bahia (o "Mapitoba") e outras inscritas na região Amazônica (Sauer; Leite, 2011), resultando na derrubada da floresta, sua substituição por lavouras de grãos e a ampliação da exportação de commodities, o que implica a exportação de outros bens comuns, especialmente a água. As estimativas são de que a produção de um quilo de grãos consome em torno de um metro cúbico de água (Franca; Cardoso Neto, 2006). Portanto, exportar grãos é exportar água. ${ }^{29}$

Esse aumento da fronteira agrícola, entre outros fatores, está intimamente associado à alta de preços das commodities no mercado internacional (Sauer; Leite, 2011). Se, de um lado, essa alta de preços gera "oportunidades de negócios" - e as alterações do Código Florestal estão diretamente relacionadas a isso -, por outro, a consequência mais nefasta foi a crise alimentar (FAO, 2011a). Em 2008, essa crise alimentar, na verdade, crise provocada por uma alta generalizada dos preços

${ }^{29}$ De acordo com estimativas da Organização das Nações Unidas para Agricultura e Alimentação (FAO), a agricultura ocupa $11 \%$ da superfície terrestre mundial em cultivos e usa $70 \%$ de toda água retirada de lençóis freáticos, córregos e lagos (FAO, 2011, p.13). 
dos alimentos, fez o número de famintos chegar a um bilhão de pessoas no mundo, sendo que esse número cresceu em 8\% na África (FAO, 2011a). ${ }^{30}$

Associada à alta dos preços, o estudo da Organização das Nações Unidas para Agricultura e Alimentação (FAO) previu a necessidade de aumentar a produção de alimentos em $70 \%$ até 2050 (2011a, p. 42) para alimentar uma população estimada de nove bilhões de habitantes no planeta. Essa previsão foi usada à exaustão na defesa de mudanças no Código, as quais estariam voltadas para a garantia de mais terras para a produção. Esse uso dos dados excluiu, obviamente, vários elementos apontados pelo mesmo documento, como, por exemplo, a necessidade de investimentos governamentais diretos em pesquisas e desenvolvimento agrícolas para aumentar a "[...] capacidade dos sistemas agrícolas, especialmente dos pequenos agricultores, para enfrentar as mudanças climáticas e a escassez de recursos" (FAO, 2011a, p.43).

Além de uma ênfase excessiva nas consequências do aumento populacional, em uma espécie de neo-malthusianismo da equação população e produção, a insistência no aumento da produção não considera que a FAO revisou recentemente suas estimativas, afirmando que a demanda de alimentos não será tão intensa como originalmente se previu. Por outro lado, não há recursos (terra, água) suficientes para suprir as necessidades alimentares da população em 2050 apenas com o aumento da área plantada. São fundamentais outras ações, desde o combate ao desperdício (FAO, 2011a), ${ }^{31}$ passando por ganhos de produtividade, mas especialmente mudanças no atual regime de distribuição e consumo dos alimentos. Consequentemente, “[...] os padrões dominantes de produção agrícola precisam ser

${ }^{30} \mathrm{O}$ documento da FAO (2011a, p.11) elencou várias razões para essa crise alimentar e o aumento dos preços, como, por exemplo, "[...] as políticas para promover o uso de biocombustíveis (tarifas, subsídios e níveis obrigatórios de consumo), que aumentaram a demanda por óleos vegetais e de milho".

${ }^{31}$ Segundo o mesmo documento, "[...] recentemente a FAO estimou que 1,3 bilhões de toneladas de alimentos são perdidos ou desperdiçados a cada ano no mundo" (FAO, 2011a, p.42). criticamente revistos” (2011, p.10).

Sem sombra de dúvidas, a inclusão da temática da segurança ou insegurança alimentar faz parte das tentativas de ganhar a opinião pública em apoio às mudanças na legislação ambiental. Isso levou à proposta, entre várias outras, de ampliação do conteúdo do "interesse social”, conceito introduzido no Código pela MP 2.166, de 2001, conforme vimos anteriormente. O exemplo mais explícito foi a apresentação do Projeto de Lei $n^{\circ} 5.367$, de 2009, do Dep. Valdir Colatto (PMDB/SC), cuja proposta do Código Ambiental Brasileiro definia que "[...] as atividades rurais de produção de gêneros alimentícios, vegetal e animal, são consideradas atividades de interesse social" (art. 10). ${ }^{32}$

Segundo Araújo et al (2009), esse artigo deve ser analisado em conjunto com o art. 80 do mesmo projeto, o qual autorizava a supressão de "mata ciliar nativa protetora de nascentes ou corpos hídricos naturais" por interesse social. Segundo tal análise, a "[...] intenção parece ser eliminar qualquer entrave para a supressão de vegetação tendo em vista a produção agropecuária" (Araújo et al, 2009, p.21), representando um risco e um retrocesso não só na preservação e conservação ambientais, mas na própria noção de segurança alimentar.

Há uma simbiose ou interdependência entre a conservação ambiental e a segurança alimentar, pois a produção agrícola depende da disponibilidade de serviços ecossistêmicos. Nesse sentido, a FAO (2011) alerta para o fato de que os atuais sistemas de uso da terra e água correm riscos de colapso em sua capacidade produtiva, devido às práticas agrícolas insustentáveis como, por exemplo, uso excessivo e incorreto de irrigação, contaminação e degradação dos solos. Em relação ao uso insustentável do solo, 25\% das terras agricultáveis estão altamente degradadas e 8\% estão moderadamente degradadas (2011, p.18), comprometendo a produção mundial de alimentos.

\footnotetext{
${ }^{32}$ Essa proposta foi efetivamente apresentada pelo Dep. Aldo Rebelo em uma de suas versões do relatório, em 02 de maio de 2011 (França, 2011).
} 
Ainda segundo o referido documento, a produção agrícola mundial aumentou em torno de duas a três vezes nos últimos 50 anos, sendo que "[...] mais de 40 por cento do aumento na produção de alimentos veio de áreas irrigadas, que duplicou em área” (FAO, 2011, p.13). Essa produção irrigada continua crescendo a taxas de 0,6 ao ano, mas isso traz desafios ambientais, a começar por uma crescente pressão sobre esse recurso escasso, que é a água. Além disso, a intensificação agrícola "[...] tem resultado em degradação ambiental grave, incluindo a perda da biodiversidade e a poluição das águas de superfície e subterrâneas e uso impróprio de fertilizantes e pesticidas" (2011, p.17).

No Brasil, não há estudos abrangentes sobre a degradação dos solos, pois os dados do IBGE são autodeclaratórios, resultando em grandes distorções (dados subestimados) nos resultados. Em todos os casos, as estimativas são de perdas anuais de solo da ordem de 822,6 milhões de toneladas, resultando em perdas 171 milhões de $\mathrm{m}^{3}$ de água (ABC; SPBC, 2011, p.41). Essa perda de solos e erosão hídrica impacta diretamente na capacidade produtiva agrícola (ANA, 2010), gerando situações de insegurança alimentar. É fundamental, portanto, a proteção dos recursos hídricos, sendo que a legislação ambiental "[...] não necessita de alterações em relação às exigências estabelecidas" (2010).

Em relação aos recursos hídricos, a água é, antes de qualquer coisa, alimento, ou seja, água não pode ser vista apenas como um recurso ou componente na produção de alimentos, como, por exemplo, no cultivo de cereais ou no aumento da produtividade agrícola através do cultivo de lavouras irrigadas. ${ }^{33}$ Água, antes de um recurso hídrico, é essencial no consumo humano direto; portanto, é um componente fundamental do direito humano à alimentação adequada e saudável. ${ }^{34} \mathrm{Em}$ outras palavras, a pre-

${ }^{33}$ O próprio relatório da FAO (2011a) sobre a situação mundial da água e da terra considera (levanta dados) apenas da água como "fator de produção", considerando seu uso crescente na agricultura irrigada e os riscos de desertificação, como riscos à produção agrícola. servação de nascentes, córregos e rios é parte fundamental das estratégias de soberania e segurança alimentar, não apenas pela necessidade de produção de alimentos, mas também como um componente essencial e indispensável à vida, "um bem de domínio público" e um "recursos natural limitado" (Lei 9.433, 1997).

Diante da obscenidade da fome mundial, o desafio é criar instrumentos e mecanismos para garantir o direito à alimentação adequada e saudável, agora um mandato constitucional, segundo art. $6^{\circ}$, da Carta Magna brasileira. Certamente, essa garantia não se dará somente com medidas para aumentar a produção agropecuária, pois segurança ou soberania alimentar, além da quantidade de calorias, significa também qualidade dos alimentos, pois o direito é por alimentos saudáveis. Nesse sentido, é fundamental um meio ambiente (fauna, flora, cursos de água, nascentes, lençol freático etc.) capaz de produzir alimentos saudáveis, exigindo, inclusive, mudanças no uso de agrotóxicos (contaminação de alimentos e do meio ambiente).

Conforme claramente apontado pelo estudo da SBPC e ABC, há vínculos diretos entre a necessidade de preservar ou conservar o meio ambiente e a sustentabilidade produtiva brasileira, consequentemente com a soberania alimentar. Segundo essas entidades científicas, faz-se fundamental entender e considerar os "serviços ecossistêmicos", pois as Áreas de Preservação Permanente e de Reserva Legal são áreas que “[...] fazem parte de uma estratégia produtiva que potencializa a conservação da água, do solo e da agrobiodiversidade" (ABC; SBPC, 2011, p.38).

Ainda segundo os estudos da SPBC e ABC (2011, p.52), quatro serviços ecossistêmicos das APPs e Reserva Legal são fundamentais para a sustentabilidade dos sistemas produtivos agrícolas:

${ }^{34}$ Apesar de constatação tão elementar, a preservação da água e a sua distribuição (ampliação da rede de abastecimento, fornecimento de água potável às populações pobres etc.) não aparecem entre as diretrizes do Plano Nacional de Segurança Alimentar e Nutricional 2012-2015 (CAISAN, 2011). 
a) a regulação hidrológica (aumento do armazenamento, transferência e recarga de aquíferos); b) regulação atmosférica (maior sequestro de carbono e redução de gases causadores do efeito estufa); c) o controle da erosão; d) serviços ofertados pela biodiversidade (polinização e controle de pragas agrícolas).

Consequentemente, a preservação das APPs é, antes de tudo, uma condição sine qua non para a segurança e soberania alimentar do Brasil. Diferentemente de teses que afirmam que as leis ambientais "[...] imobilizam riquezas em benefício das nações desenvolvidas” (Rebelo, 2011b), a proteção das APPs e da Reserva Legal deve fazer parte das estratégias de desenvolvimento socioeconômico sustentável (ABC; SBPC, 2011), incentivando a agricultura familiar a conservar e a recuperar suas reservas como mecanismos de auferir rendimentos mediante o uso sustentável (IPEA, 2011).

\section{NOTAS CONCLUSIVAS}

A esmagadora maioria das propostas e mudanças até aqui feitas ao texto atual do Código Florestal representa processos, em médio e longo prazos, de disfunção socioambiental da terra e insegurança alimentar. Seja partindo da afirmação do direito absoluto de propriedade, seja sustentando a necessidade de produzir alimentos para saciar a fome do mundo, as propostas e alterações têm como propósito manter o uso ilegal de áreas que deveriam ser conservadas ou preservadas, representando riscos reais à biodiversidade brasileira.

A lógica central das mudanças tem sido mesmo a manutenção do uso ilegal de Áreas de Preservação Permanente e de Reserva Legal, ameaçando a biodiversidade e a sustentabilidade dos processos produtivos, como bem apontaram os estudos da ABC, da SPBC e do IPEA. Na contramão dos compromissos internacionais assumidos pelo Brasil, as mudanças reafirmam a necessidade de ampliar a produção agropecuária contra a natureza, avançando sobre APPs e Re- serva Legal, as quais são fundamentais, pois prestam serviços ecossistêmicos, tornando o modelo produtivo ainda mais predatório e insustentável.

Por outro lado, as regras que flexibilizam as exigências de recomposição, a adoção do conceito de área rural consolidada, que ameaça a existência de mata ciliar, passando pela subtração de áreas que deixam de ser de preservação, representam tentativas de ampliar o uso de áreas que deveriam ser conservadas ou preservadas. Mesmo criando disposições transitórias para resolver o passivo ambiental (irregularidades do passado), as flexibilizações adotadas no Senado e as alterações propostas à MP 571, de 2012, ameaçam uma legislação que tinha como objetivo impedir novos avanços sobre áreas de preservação. As propostas acabam consolidando perdas passadas, mantendo os riscos ambientais futuros, como, por exemplo, a ampliação de atividades agrossilvopastoris em áreas de declive, acentuado ou provocando erosões, entre outros danos ambientais, ou mesmo as tentativas de definir faixas de APPs ripárias somente para rios perenes, desprotegendo, assim, os cursos d’água intermitentes.

As tentativas (ou justificativas) de criar uma lei moderna, baseada em incentivos e não em comando e repressão, acabam sendo completamente ameaçadas pelos retrocessos na lógica conservacionista da lei em vigor. As compensações por serviços ambientais, na perspectiva de criar condições para uma economia verde, são ofuscadas por lógicas predatórias, aprofundando o histórico modelo de produção agropecuária economicamente expropriatória, ecologicamente degradante e socioambientalmente insustentável.

(Recebido para publicação em 10 de abril de 2012) (Aceito em 09 de julho de 2012)

\section{REFERÊNCIAS}

ABC. Academia Brasileira de Ciências; SBPC. Sociedade Brasileira para o Progresso da Ciência. O Código Florestal e a Ciência: contribuições para o diálogo. São Paulo: SBPC, 2011. 
Carta aberta SBPC e ABC. 27 de fevereiro de 2012. Disponível em: www. sbpcnet.org.br/site/arquivos/ carta_aberta.pdf. Acesso em: 15 fev. 2012.

ABREU, Sen. Kátia. Notas taquigráficas da $47^{a}$ Reunião Ordinária da CCJ. 21 set. 2011. Brasília: Senado Federal, 2011.

Pronunciamento no Plenário do Senado Federal, o6 de junho. Brasília, Senado Federal, 2011a. Disponível em: www.senado.gov.br/atividade/pronunciamento/ detTexto. asp?t=388478. Acesso em: 08 mar. 2012.

Reserva Legal atrapalha atividade econômica. $O$

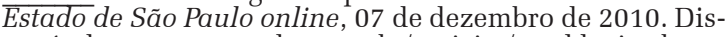
ponível em: www.estadao.com.br/noticias/geral,katia-abreureserva-legal-atrapalha-atividade-economica,650608,0.htm. Acesso em: 10 mar. 2012.

ANA. Agência Nacional de Águas. Nota técnica nº 045/2010SIP-ANA. Brasília: 2010.

ARAÚJO, Suely M. V. Guimarães de. PL 5.367/2009 (Código Ambiental Brasileiro): análise crítica. Brasília: Câmara dos Deputados, 2009.

; JURAS, Ilidia da A. G. Martins. Substitutivo ao PL 1.876/1999 e apensos (Código Florestal): análise crítica. Brasília: Câmara dos Deputados, 2010.

BENJAMIN, Antônio Herman. Mudança no Código Florestal prejudicará a Reforma Agrária. Folha de São Paulo, 20 jul. 2011.

BRASIL. Constituição da República Federativa do Brasil. Brasília: Senado Federal, 2006.

Presidência da República. Lei 12.651, de 25 de maio de 2012, Brasília, 2012. Disponível em: https:// www.planalto.gov.br/ccivil_03/_ato2011-2014/2012/lei/ 112651.htm Acesso em: 23 aḡo. $2 \overline{0} 12$.

Presidência da República. Decreto $n^{\circ}$ 6.040, de 2007. Institui a Política Nacional de Desenvolvimento Sustentável dos Povos e Comunidades Tradicionais, 07 fev. 2007. Brasília: 2007.

CAISAN. Câmara Interministerial de Segurança Alimentar e Nutricional. Plano Nacional de Segurança Alimentar e Nutricional-2012-2015. Brasília: MDS, Consea, 2011.

COLATTO, Dep.Valdir. Projeto de Lei $n^{\circ} 5.367$, Código Ambiental Brasileiro. Brasília: Câmara dos Deputados, 2009.

COMPARATO, Fábio K. Prefácio. MELO, Dep. João Alfredo (Org.) Reforma agrária quando? CPI mostra as causas da luta pela terra no Brasil. Brasília: Senado Federal, 2006, p.13ss.

CONSEA. Conselho Nacional de Segurança Alimentar e Nutricional. Relatório final da III Conferência Nacional de Segurança Alimentar e Nutricional, Brasília, 2007. Disponível em: www.planalto.gov.br/consea/3conferencia/static/ Documentos/RelatorioFinal.pdf. Acesso em: 15 mar. 2012.

DELGADO, Nelson G. O papel do rural no desenvolvimento nacional: da modernizaç̃o conservadora dos anos 1970 ao Governo Lula. In: BRASIL. Ministério do Desenvolvimento Agrário. Brasil rural em debate. Brasília: CONDRAF/ MDA, 2010, p.28-78.

FAO. Organização das Nações Unidas para a Agricultura e Alimentação. The state of the world's land and water resources for food and agriculture (SOLAW) - Managing systems at risk. FAO, Roma, 2011. Disponível em: www.fao.org/docrep/015/i1688e/i1688e00.pdf. Acesso em: 30 mar. 2012.

The State of Food Insecurity in the world: how does international price volatility affect domestic economies and food security? FAO, Roma, 2011a. Disponível em: www.fao. org/docrep/014/ i2330e/i2330e.pdf. Acesso em: 10 fev. 2012.

FRANCA, Dalvino T.; CARDOSO NETO, Antônio. Água e sociedade. Plenarium, Brasília, Câmara dos Deputados, v.3, n.3, set. p.20-28, 2006.

FRANÇA, Franciney F. et al. Código Florestal: considerações sobre a redação final PL 1.876 C, de 1999. Brasília: Senado Federal, 30 de maio de 2011 (mimeo).

Código Florestal: perto do fim das negociações na Câmara. Brasília: Senado Federal, 27 de abril de 2011 (mimeo).

FREITAS, Cristina Godoy de Araujo. Notas taquigráficas da audiência pública - CMA, CCJ, CRA e CCT. Brasília, Senado Federal, 13 de setembro de 2011. Disponível em: www. senado.gov.br/atividade/comissoes/ses sao/disc/ listaDisc.asp?s=000567/11. Acesso em: 20 fev. 2012.

HOFFMANN, Rodolfo, NEY, Marlon. A distribuição da posse da terra e a recente queda da desigualdade de renda no Brasil. In: ENCONTRO DA SOBER,47, Porto Alegre, 2009. Disponível em: www.sober.org.br/palestra/13/361.pdf. Acesso em: 20 fev. 2012

IBGE. Instituto Brasileiro de Geografia e Estatística. Censo agropecuário 2006. Rio de Janeiro: 2009. Disponível em: www.ibge.gov.br/home/estatistica/economia/agropecuaria/ censoagro/default.shtm. Acesso em: 20 jun. 2012.

Censo Agropecuário 2006: agricultura familiar primeiros resultados. Rio de Janeiro: 2009a.

Produção Agrícola Municipal: culturas temporárias e permanentes. Rio de Janeiro, 2990b. Disponível em: http://www.sidra.ibge.gov.br/ Acesso em : 20 jun. 2012.

IPEA. Instituto de Pesquisa Econômica Aplicada. Código Florestal: implicações do PL 1876/99 nas áreas de Reserva Legal. Comunicados do IPEA. Brasília: 08 de junho de 2011.

LIMA, Titan; FERNANDES, Uelton. Código Florestal: pontos sobre os textos apresentados, 11 de maio de 2011 Brasília: Câmara dos Deputados, 2011 (mimeo).

- INTINI, João Marcelo. A agricultura familiar no novo Código Florestal. Brasília: Câmara dos Deputados, 2012 (mimeo).

LORENZONI, Dep. Onyx. Notas taquigráficas do plenário da Câmara - sessã̃o 105.1.54. Brasília: Câmara dos Deputados. Disponível em: www.camara.gov.br/internet/sitaqweb/ TextoHTML.asp?etapa $=5 \&$ nuSessao $=105.1 .54$. Acesso em: 10 abr. 2012

MARÉS, Carlos F. A função social da terra. Porto Alegre: Sergio Antonio Fabris Ed., 2003.

MARTINS, José de Souza. O poder do atraso: ensaios de sociologia da história lenta. São Paulo: Editora Hucitec, 1994. . A chegada do estranho. São Paulo: Hucitec, 1993.

Caminhada no chão da noite: emancipação política e libertação nos movimentos sociais do campo. São Paulo: Hucitec, 1989.

MDA. Ministério do Desenvolvimento Agrário. II Plano Nacional de Reforma Agrária: paz, produção e qualidade de vida no meio rural. Brasília: INCRA, 2005.

MDS. Ministério do Desenvolvimento Social e Combate à Fome. Brasil sem miséria. Brasília: 2011. Disponível em: www.brasilsemmiseria.gov.br/ Acesso em: 20 maio 2012.

PAULINO, Eliane Tomiasi. A mudança do Código Florestal brasileiro: em jogo a função social da propriedade. CampoTerritório: revista de geografia agrária, v.7, nº.13, p. 40-64, fev., 2012.

REBELO, Dep. Aldo. Parecer do relator ao Projeto de Lei $n^{\circ}$ 1876/99 e apensados. Brasília: Câmara dos Deputados, 24 de maio de 2011 .

Relatório Substitutivo aprovado na Comissão Especial. Brasília: Câmara dos Deputados, 2010. 
. O Código Florestal e a questão nacional. Folha de São Paulo, jun. 2011a. Tendências e debates, p.A314.

Código Florestal, o equilíbrio possível. O Estado de São Paulo. 30 abr. 2011b.

RUSSO, Oswaldo. A constituinte e a Reforma Agrária. In CONSTITUIÇÃO 20 ANOS: Estado, democracia e participação popular. Brasília: Câmara dos Deputados, 2009 , p.179ss. (Série ação parlamentar, n.393)

SABBATO, A. A intervenção no mercado de terras rurais no Brasil: um estudo sobre o crédito fundiário e o Imposto Territorial Rural no período 1997-2002. 2008. Tese (Doutorado) - CPDA, /Universidade Federal do Rio de Janeiro. 2008.

SAUER, Sérgio: LEITE, Sérgio P. Agrarian structure, foreign investments on land, and land price in Brazil. In: INTERNATIONAL CONFERENCE ON GLOBAL LAND GRABBING, Anais... Universidade de Sussex, 2011. Disponível em: www.future-agricultures.org/papers-andpresentations/cat view/1551-global-land-grab/1552 conference-papers?start=10. Acesso em: 20 fev. 2102.

Expansão do agribusiness, mercado de terras e estrangeirização da propriedade rural no Brasil: notas críticas sobre a dinâmica recente. Revista Mundo Siglo XXI, v.7,,n.26, 2011. Disponivel em: www.ciecas.ipn.mx 03wspub/01pubrevi/26_msXXI/rmundoXXI_26.html Acesso em: 15 mar.2102.

SAUER, Sérgio. Consideracões finais: Apontamentos para a continuidade do (em)debate territorial. In: SAUER, S. ALMEIDA, W. (Org.) Terras e territórios na Amazônia: demandas, desafios e perspectivas. Brasília: Ed. Da UnB, 2011. p.411ss.
. Terra e modernidade: a reinvenção do campo brasileiro. São Paulo: Expressão Popular, 2010.

SCHAEFFER-NOVELLI, Yara et al. Alguns impactos do PL 30/2011 sobre os Manguezais brasileiros. In: COMITE BRASIL EM DEFESA DAS FLORESTAS E DO DESENVOLVIMENTO SUSTENTÁVEL. Código Florestal e a Ciência. Brasília: 2012.

SILVA, José Gomes da. Buraco negro: a reforma agrária na constituinte de 1987-88. Rio de Janeiro: Paz e Terra, 1989.

SILVEIRA, Sen. Luiz Henrique da. Relatório da CCT e da CRA. 09 nov. 2011. Brasília: Senado Federal, 2011.

SOUZA, Marcos R.; SAUER, Sérgio. A reforma agrária e a Constituição. In: CONSTITUIÇAOO 20 ANOS: Estado, democracia e participação popular. Brasília: Câmara dos Deputados, 2009. p.145ss.(Série ação parlamentar, n.393)

VIANA, Sen. Jorge. Parecer do relator ao Projeto de Lei da Câmara no 30/2011. 06 de dezembro de 2011. Brasília: Senado Federal, 2011.

. Parecer aprovado na Comissão de Meio Ambiente (CMA). Brasília, Senado Federal, 2011a. Disponível em: www.senado.gov.br/atividade/materia/detalhes.asp?p cod _mate=100475. Acesso em: 20 jun. 2012. 


\section{FOREST CODE, SOCIOENVIROMENTAL FUNCTION OF THE EARTH AND FOOD SOVEREIGNTY}

\author{
Sérgio Sauer \\ Franciney Carreiro de França
}

This paper aims at discussing the modifications in the Forest Code, especially the proposals of changes in the concepts of Legal Reserve and Permanent Preservation Area (PPA), which undergo a rediscussion process in the House of Representatives, after a presidential enactment with vetoes in the text approved in the House of Representatives on 25 April 2012. To fill in the gaps of the new Law, the Executive Branch edited the first Provisional Measure (PM) $571 / 2012$, which resumes the discussion of the subject. Both the provisions of the New Law and the modifications proposed to the MP text generate food insecurity and aim at eliminating the socioenvironmental function of the earth. The motivation of changes is not related to environmental sustainability or to climatic changes, key issues in the international agenda, but rather to the principle that nature is an obstacle to development. This paper recovers the major modifications in the Forest Code related to the Legal Reserve and to the PPAs, establishing relations (negative impacts) with the socioenvironmental function of the earth and food sovereignty.

KEY wORDS: Environmental code, social and environmental function of the earth, food safety, sustainability.

\section{CODE FORESTIER, FONCTION SOCIALE ET ENVIRONNEMENTALE DE LA TERRE ET SOUVERAINETÉ ALIMENTAIRE}

\author{
Sérgio Sauer \\ Franciney Carreiro de França
}

Cet article vise à discuter des changements du Code Forestier, notamment de ceux proposés concernant les notions de Réserve Légale et d'Aires de Préservation Permanente (APP) qui sont en train d'être revues au Congrès après l'approbation présidentielle avec droit de veto dans le texte approuvé par la Chambre le 25 avril 2012. Afin de combler les lacunes de la nouvelle Loi, le Pouvoir Exécutif Fédéral a publié la Mesure Provisoire (MP) 571/2012 qui relance le débat en la matière. Autant les dispositifs de cette nouvelle Loi que les modifications proposées au texte de la MP génèrent une insécurité alimentaire et visent à éliminer les fonctions sociale et environnementale de la terre. Le motif des changements n'est pas liéà la durabilité environnementale ou aux changements climatiques, questions clefs de l'agenda mondial, mais partent du principe que la nature est un obstacle au développement. Cet article reprend les principales modifications apportées au Code Forestier, liées à la Réserve Légale et aux APP, et établit les relations (impacts négatifs) avec la fonction socioenvironnementale de la terre et la souveraineté des aliments.

Mots-CLÉs: Code de l'environnement, fonction socio-environnementale de la trre, sécurité alimentaire, durabilité.

Sérgio Sauer - Doutor em Sociologia. Professor da Universidade de Brasília (UnB), campus de Planaltina (FUP), e do Programa de Pós Graduação em Meio Ambiente e Desenvolvimento Rural (PPG-MADER/FUP). Integra o Núcleo de Extensão e Pesquisa em Agroecologia (Nepeas), desenvolvendo estudos nas áreas de políticas públicas de reforma agrária, movimentos sociais agrários, agroenergias e segurança alimentar. Entre as publicações recentes estão: Agroecologia e transição agroecológica (2009) e Terra e modernidade (2010), pela Expressão Popular, e Terras e territórios na Amazônia (2011), pela Editora da UnB.

Franciney Carreiro de França - Doutora em Arquitetura e Urbanismo pela Universidade de Brasília, mestre em Arquitetura e Urbanismo (FAU-UnB), bacharel em Matemática (UFG) e Assessora Técnica no Senado Federal para as áreas de meio ambiente, habitação e cidades. Integra o Grupo de Pesquisas Dimensões Morfológicas do Processo de Urbanização - DIMPU. Entre as publicações recentes está Arquitetura \& Urbanidade, $2^{\circ}$ Edição (2011). 